\title{
Associations between Prolactin, Diabetes, and Cognitive Impairment: A Literature Review
}

\author{
Hai Duc Nguyen ${ }^{a}$ Hojin Oh ${ }^{a}$ Byung Pal Yu ${ }^{b} \quad$ Ngoc Minh Hong Hoang ${ }^{a}$ \\ Won Hee Jo ${ }^{a}$ Hae Young Chung ${ }^{c}$ Min-Sun Kim ${ }^{a}$ \\ aDepartment of Pharmacy, College of Pharmacy and Research Institute of Life and Pharmaceutical Sciences, \\ Sunchon National University, Suncheon, Republic of Korea; 'bepartment of Physiology, The University of \\ Texas Health Science Center at San Antonio, San Antonio, TX, USA; 'Department of Pharmacy, College of Pharmacy, \\ Pusan National University, Busan, Republic of Korea
}

\section{Keywords}

Prolactin - Diabetes · Alzheimer's disease - Cognitive impairment

\begin{abstract}
Background: Converging evidence indicates prolactin (PRL) and diabetes play an important role in the pathophysiology of cognitive impairment. However, little is known about the mechanisms responsible for the effects of PRL and diabetes on cognitive impairment. Summary: We summarize and review the available literature and current knowledge of the association between PRL and diabetes on aspects of cognitive impairment. Key Messages: The phosphatidylinositol 3-kinase/protein kinase B pathway is central to the molecular mechanisms underlying how PRL and diabetes interact in cognitive impairment. Further work is needed to identify the interaction between PRL and diabetes, especially in the molecular aspects of cognitive impairment, which can suggest novel strategies for cognitive dysfunction treatment.
\end{abstract}

(c) 2021 S. Karger AG, Basel

\section{Introduction}

Converging evidence suggests that diabetes predisposes to cognitive impairment and results in dementia in both in vivo models and in humans with diabetes, including type 1 diabetes (T1D), type 2 diabetes mellitus (T2DM), and gestational diabetes [1-3]. Unfortunately, diabetes and dementia are growing more prevalent around the world $[4,5]$. Thus, there is an urgent need to gain knowledge of the pathophysiological disorder and to find out a promising molecule for treatment and pathways that could be enhanced therapy in the future.

Prolactin (PRL) is a polypeptide with numerous functions, including immune regulation, lactation, reproduction, metabolism, brain function, and behavior. PRL has the potential to protect against diabetes [6]. PRL has antiinflammatory effects on the central nervous system (CNS). PRL may suppress tau phosphorylation by inactivating glycogen synthase kinase-3 (GSK3 $\beta$ ) [7]. PRL also improves memory, cognition, and learning while reducing stress and anxiety. Several genes associated with PRL-

\footnotetext{
Karger
} 
induced microglial activation may be important for hippocampus neuroimmunomodulation or neuronal cell protection [7]. Although PRL involvement in the pathogenesis of diabetes and cognitive impairment has been recognized, the interaction of PRL and diabetes in cognitive impairment is rather unknown and remains to be elucidated.

In this review, we first describe the aspects of PRL in the contexts of different types of diabetes, including T1D, T2DM, gestational diabetes, and cognitive impairment. We further reviewed the association of PRL and diabetes, including pathways and mechanisms in cognitive impairment.

\section{PRL and Diabetes}

PRL has been related to glucose metabolism. At high levels, PRL inhibits lipogenesis, but at low physiological levels, it inhibits lipolysis due to a specific effect of PRL on adipocyte differentiation via activation of peroxisome proliferator-activated receptor-gamma [8]. In the middle-aged and elderly population, high circulating PRL levels are associated with a lower prevalence of diabetes and impaired glucose regulation [9]. However, hyperprolactinemia may lead to insulin resistance and impair islet cell function [10]. PRL hormone has also been implicated as a diabetogenic factor in the pathogenesis of T2DM [11]. Although the association between PRL levels and diabetes, especially T2DM, has been widely described, little is known about the relationship between PRL and other types of diabetes such as T1D, gestational diabetes, and diabetic angiopathy. Here, we describe the effects of PRL on T1D, T2DM, gestational diabetes, and diabetic angiopathy.

\section{PRL and T1D}

Autoimmune T1D is caused by T cells infiltrating selfantigens and $\mathrm{B}$ cells producing islet-specific autoantibodies, resulting in the destruction of pancreatic cells [12]. B lymphocytes produce cytokines that both drive $\mathrm{T}$ cell differentiation and regulate their excess in inflammation. B lymphocytes can also act as cellular adjuvants for the activation of $\mathrm{CD}^{+} \mathrm{T}$ cells [13]. Additionally, since the discovery of the Toll-like receptor family, innate immunity appears to have a significant role in increasing autoreactive T- and B-lymphocyte responses in causing T1D [14, 15].

PRL receptors (PRLRs) are found in a variety of immune cells (e.g., monocytes, macrophages, microglia, neutrophils, natural killer cells, and lymphocytes), and thus, PRL has the ability to mediate effects in all of them [16]. PRL also increases T-cell activation through a variety of mechanisms. First, PRL can activate and phosphorylate cluster of differentiation (CD) 3 , second messenger kinase Fyn, and zeta chain of T-cell receptor-associated protein kinase 70 [17-19]. Second, PRL can stimulate CD25, which is known to play an important role in controlling the expansion and proliferation of T-cell subsets [20]. Third, PRL can activate CD69, which is essential for the prolonged proliferation and stimulation of T-cells $[20,21]$. Fourth, in antigen-presenting cells, PRL can increase the expression of CD40, CD80, and CD86 co-stimulatory molecules [22]. Fifth, PRL stimulates the production of cytokines that increase T-cell response, such as IL-1, IL-12, IL-16, and interferon-gamma [22, 23]. Sixth, PRL can regulate dopamine agonist sensitivity in the immune system [22]. On the other hand, PRL increases the expression of the T-box transcription factor TBX21 (Tbet) via JAK2/STAT5 in T cells [24]. Low concentrations of PRL (10-30 ng/mL) may stimulate the JAK2/STAT5mediated signaling pathway in $\mathrm{CD}^{+} \mathrm{T}$ cells, whereas high concentrations of PRL (100 ng/mL) may stimulate the SOCS1 and 3 signaling pathways, resulting in T-bet suppression $[24,25]$.

PRL, as an immunomodulator, may play a role in the onset and progression of autoimmune disorders such as T1D [26]. PRL promotes insulin secretion and islet cell proliferation. In vitro studies found that pancreatic islets in PRLR-deficient mice are smaller, denser, and have less $\beta$-cell mass compared with wild-type littermates as early as 3 weeks of life and throughout maturity [27]. PRL also stimulates PI3-kinase/MAPK in the pancreatic islets of pregnant rats [28]. Other in vivo studies discovered that PRL increased a Th2 response, possibly reflecting PRLs role in protecting mice from developing repeated lowdose streptozotocin diabetes $[29,30]$. In a study of 42 women, PRL levels had negative effects on the daily insulin dose, fasting glycemia, and HbA1c levels [31]. Table 1 describes the association between PRL and T1D in human and animal studies.

\section{PRL and T2DM}

Although numerous epidemiological studies have established the role of PRL among individuals with T2DM, the association between PRL and T2DM is still debated. A lot of evidence show that subjects with prolactinomas are more likely to develop T2DM $[49,50]$. A retrospective study of 174 T2DM patients observed that macroprolactinemia prevalence in T2DM patients is higher than in 


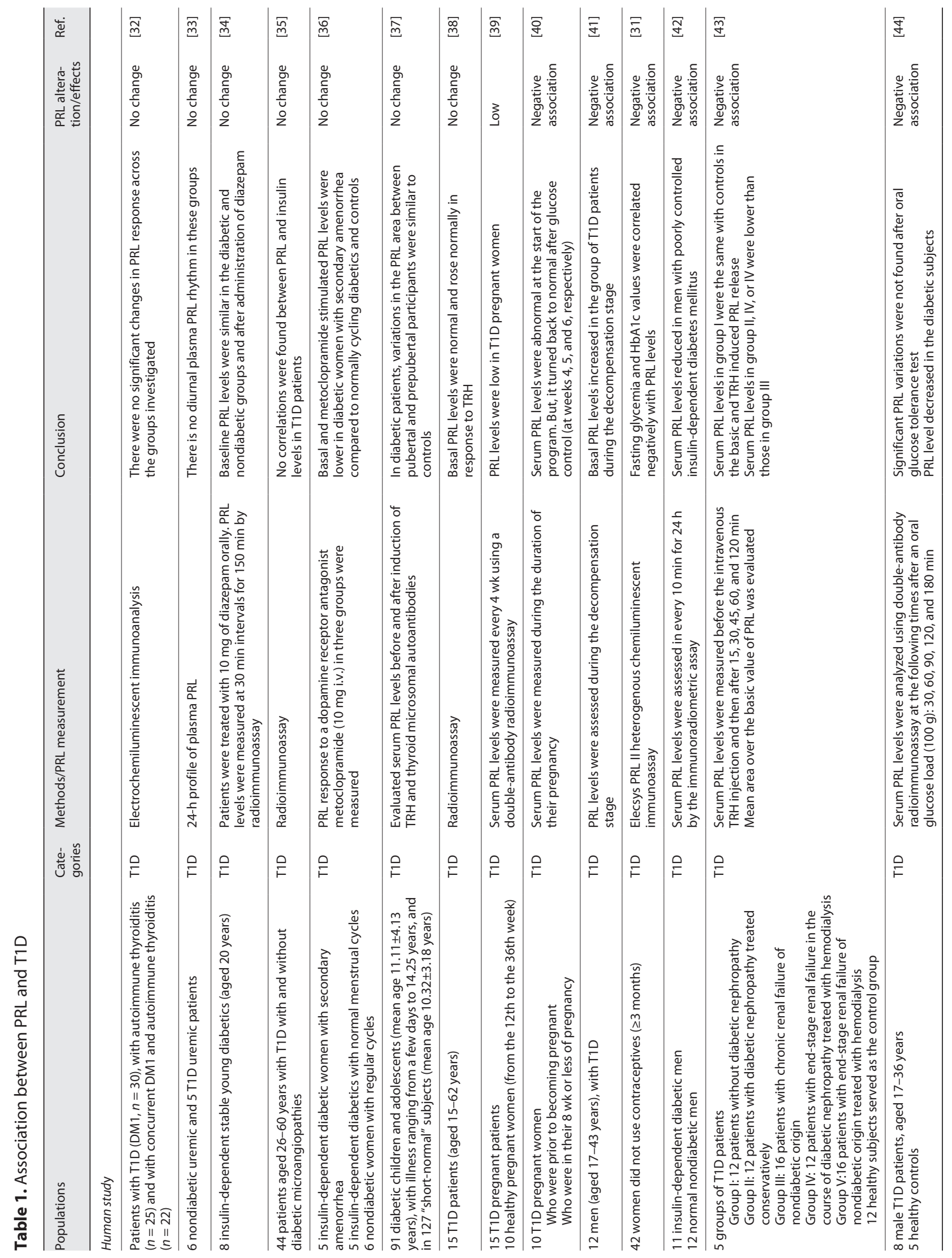




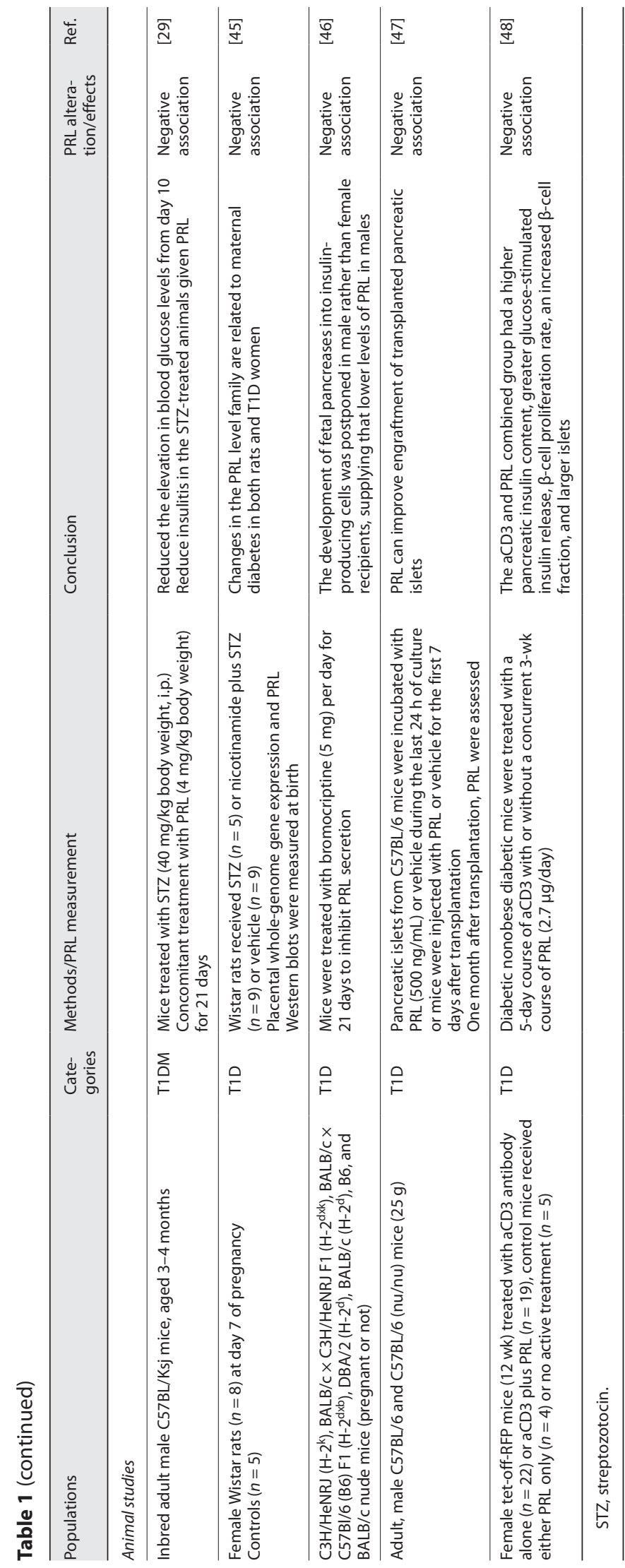

Interaction between Prolactin and Diabetes in Neurodegeneration nondiabetic patients. T2DM patients with macroprolactinemia had higher HbA1c levels than T2DM patients without macroprolactinemia [51]. It is possible to explain that reduced adiponectin expression in adipose tissue is one mechanism underlying dysregulation of glucose homeostasis in the context of hyperprolactinemia, which leads to decreased fatty-acid oxidation in muscle and decreased fatty-acid uptake by hepatocytes, both of which negatively affect insulin sensitivity [52-55]. There is evidence that treatment with dopaminergic agonists for hyperprolactinemia can improve metabolic homeostasis and decrease the risk of T2DM $[55,56]$. However, another study found that the correlation between prolactinemia and glycemia, insulinemia, and lipacidemia was low in 98 T2DM patients, implying that hyperprolactinemia does not play an important role as an extra diabetogenic factor in T2DM patients [57].

PRL has been shown to protect beta cells at physiological levels [58-60]. When diabetic rats are given low doses of PRL, their beta-cell activity and insulin sensitivity increase [61]. Beta-cell survival in culture is improved by recombinant PRL because apoptosis is reduced [59]. By stimulating glucokinase, PRL also increases insulin gene transcription and decreases the setpoint for glucose-induced insulin secretion [60]. A recent systematic review and meta-analysis also showed the positive effects of PRL levels within the normal range on the prevalence of developing T2DM but not the incidence of T2DM [6]. However, a cohort study of 3,232 T2DM patients observed that a 5-mg/dL increase in the PRL level was linked to a higher risk of developing T2DM in males (OR 1.70, 95\% CI 1.04-2.78) [62]. Other evidence indicates an increased PRL serum level in T2DM patients is associated with diabetic complications, insulin resistance, and metabolic syndrome (which is a risk factor for T2DM) [62-64]. Table 2 describes the association between PRL and T2DM in human and animal studies.

\section{PRL and Gestational Diabetes}

PRL is essential for the maintenance of the corpora lutea during pregnancy and the synthesis of milk during lactation [95]. PRL levels were found to be higher than physiological levels during pregnancy or lactation, which is metabolically beneficial. In fact, this change is seen as part of a homeostatic response to the particular metabolic demands of the mother and child, rather than as a diabetogenic factor [6].

A cohort study followed up 367 women in the late2nd/early-3rd trimester, suggesting that women with decreased PRL levels during pregnancy have a high risk of 


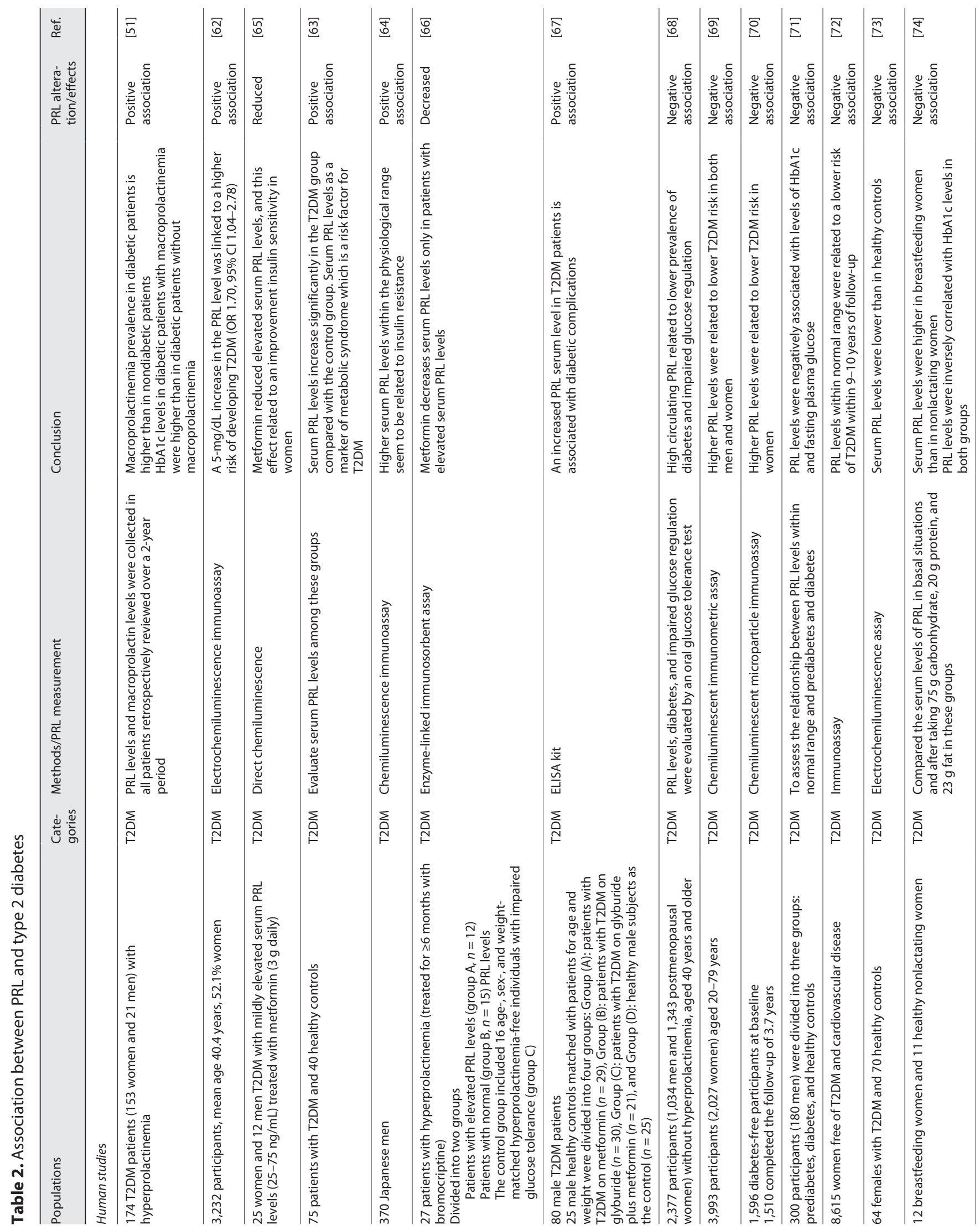




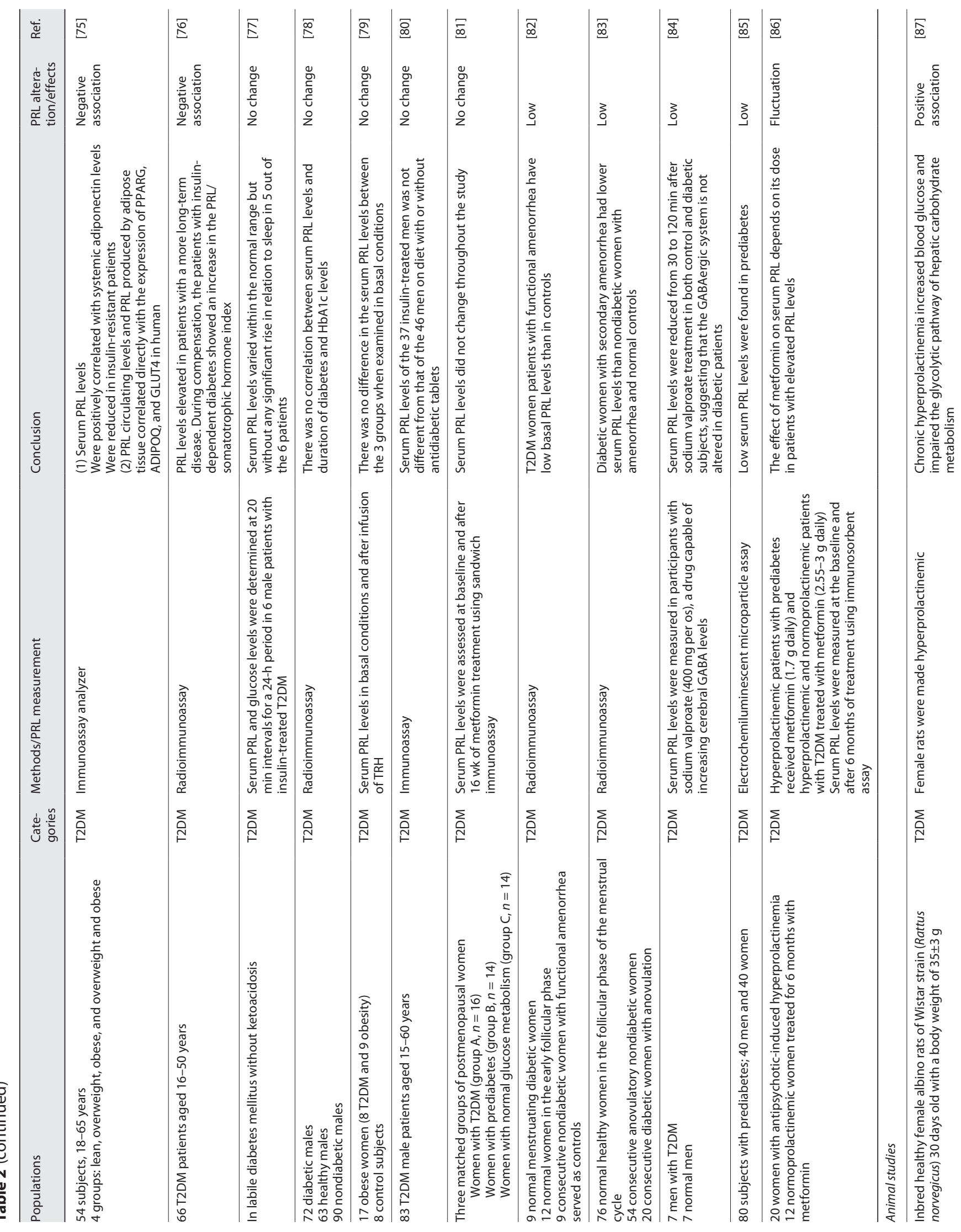




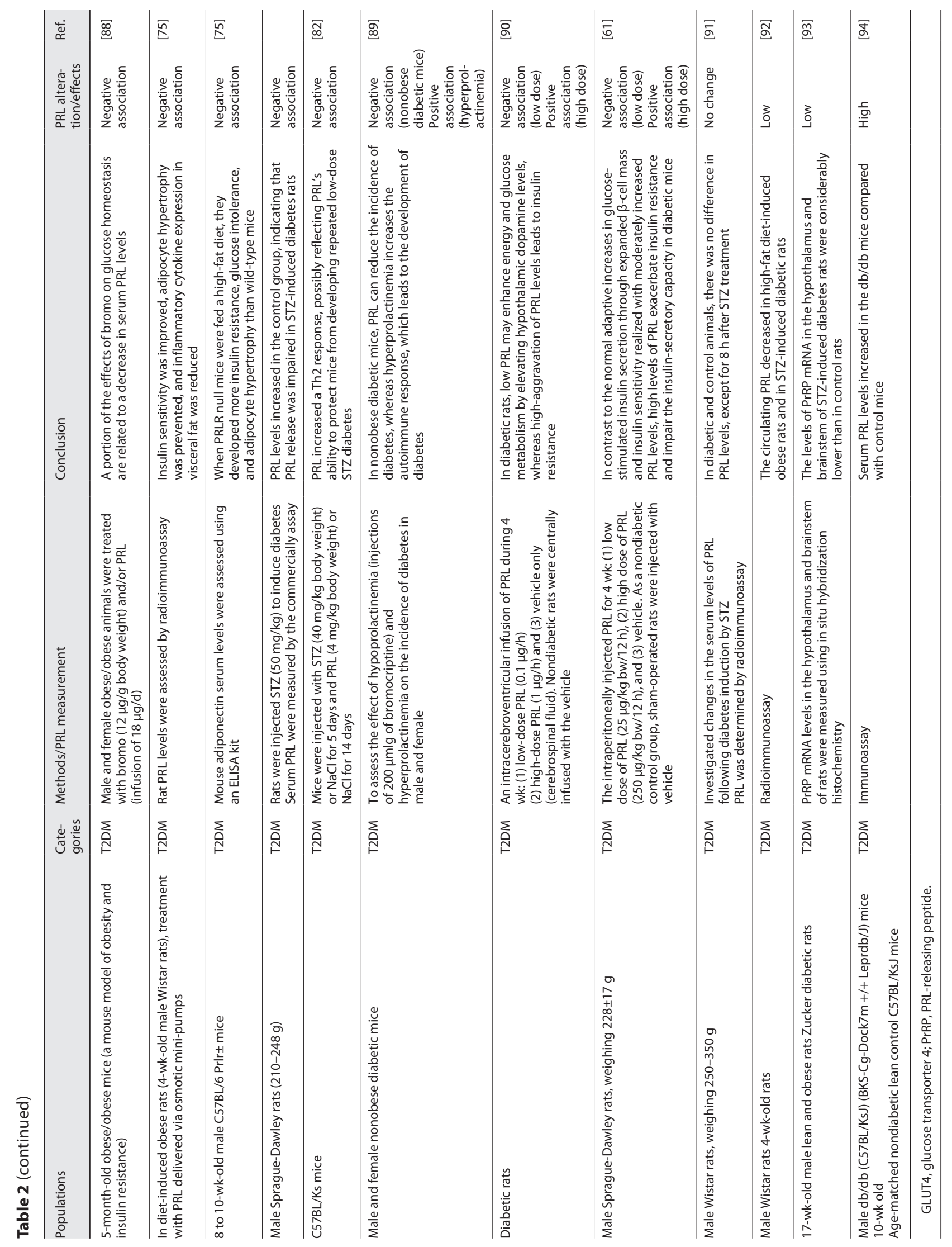

862 
developing postpartum prediabetes or diabetes [96]. In vivo studies also showed that PRL signaling plays an important role in beta-cell proliferation during pregnancy and protection against gestational diabetes in PRLR knockout mice $[97,98]$. Conversely, a cohort study reported that gestational diabetes risk was significantly and positively linked with PRL levels at weeks 10-14, implying that higher PRL levels in early pregnancy may play a role in the pathophysiology of gestational diabetes [99]. The association between PRL and gestational diabetes is still under debate (Table 3). Further work is needed to further clarify the mechanisms in which PRL is involved in the pathophysiology of gestational diabetes.

\section{PRL and Diabetic Angiopathy}

In diabetics, angiopathy can take the form of microangiopathy, macroangiopathy, or both. Retinopathy and nephropathy are microangiopathic consequences of diabetes that are two major types of diabetic microangiopathy that have been linked to cognitive impairments in diabetic patients.

There is a report of DM patients with impaired renal function showing high urine PRL levels compared to healthy controls. In that study, it was proposed that urine PRL excretion in proteinuria may contribute to renal impairment-induced PRL dysregulation [106]. Similarly, serum PRL and macroprolactin were elevated in 234 T2DM patients with different nephropathy stages, especially in patients with moderate to severe renal failure [105].

Regarding the association of PRL with diabetic retinopathy, PRL showed that it protected against diabetic retinopathy [109]. Because PRL is pro-angiogenic and acquires antiangiogenic properties after undergoing proteolytic cleavage to vasoinhibins, a PRL fragment is capable of preventing vasopermeability, vasodilation, and angiogenesis [111].

\section{Factors Affecting PRL in Diabetes}

As discussed above, the role of PRL in diabetes is becoming more widely acknowledged. However, there are several factors that can influence the excretion of PRL in diabetes.

Serum levels of several pituitary hormones (including PRL) were found to be affected by metformin. Previous research indicated that diabetic medication, primarily metformin, reduced PRL serum levels in T2DM patients by reducing insulin resistance [67]. Metformin medication may have some effects on hyperprolactinemic patients who are also on dopamine agonist therapy and have glucose metabolism disturbances [66]. In a study of 34

Interaction between Prolactin and

Diabetes in Neurodegeneration elderly women with subclinical hypothyroidism, 16 of whom were given antipsychotic medications. These women were also treated with metformin because they had T2DM (2.55-3 g daily). Serum PRL levels and HOMA1-IR were higher in antipsychotic-treated than in antipsychotic-naive women. Metformin only decreased serum PRL levels in antipsychotic-treated women, implying that the effect of metformin on serum PRL levels was stronger in antipsychotic-treated women than in antipsychotic-naive women [112]. In a study of 7 diabetics and 7 normal men treated with sodium valproate $(400 \mathrm{mg})$, a drug capable of increasing cerebral GABA concentrations, a significant decrease in serum PRL levels from 30 to $120 \mathrm{~min}$ was found after administration in both groups [84]. Several studies have highlighted the role of RPL in diabetic retinopathy, mediated by different molecules or drugs such as sulpiride and levosulpiride. Its relationship to diabetic retinopathy is described in Table 3.

There is evidence that hormonal changes can affect PRL levels in diabetes. An in vivo investigation of streptozotocin-induced diabetes $(100 \mathrm{mg} / \mathrm{kg})$ in rats revealed that testosterone has a function in regulating PRL and PRLR levels in diabetes [113]. A group of 13 juvenileonset T1D in the middle to late stages of puberty (stages 3-4) was recruited to examine PRL response to TRH. In terms of maximum value and maximum increment above baseline value, the PRL response to TRH was slightly but significantly supranormal under similar conditions of metabolic control [114]. Anovulation in diabetic patients is caused by hypothalamic and/or pituitary abnormalities. Diabetic women with secondary amenorrhea showed lower serum PRL levels than nondiabetic women with amenorrhea and normal controls [83].

\section{Possible Mechanisms between PRL and Diabetes}

The exact mechanisms of PRL and diabetes are still unclear. In reality, the effect of PRL on glucose metabolism and insulin resistance is dependent on the levels of PRL in circulation [9]. By increasing hepatic insulin sensitivity and beta-cell mass, physiologically elevated PRL levels can promote normal adaptive increases in glucosestimulated insulin production [27, 115]. Physiologically elevated PRL concentrations also have an indirect effect by enhancing hypothalamic dopamine production, which helps to maintain energy and glucose balance $[90,116]$. A previous study showed that increased PRL concentrations in T2DM may represent a compensatory mechanism against hyperglycemia because PRL plays a critical role in the increase of pancreatic-cell activity to overcome insulin resistance [117]. Several possible mechanisms can 


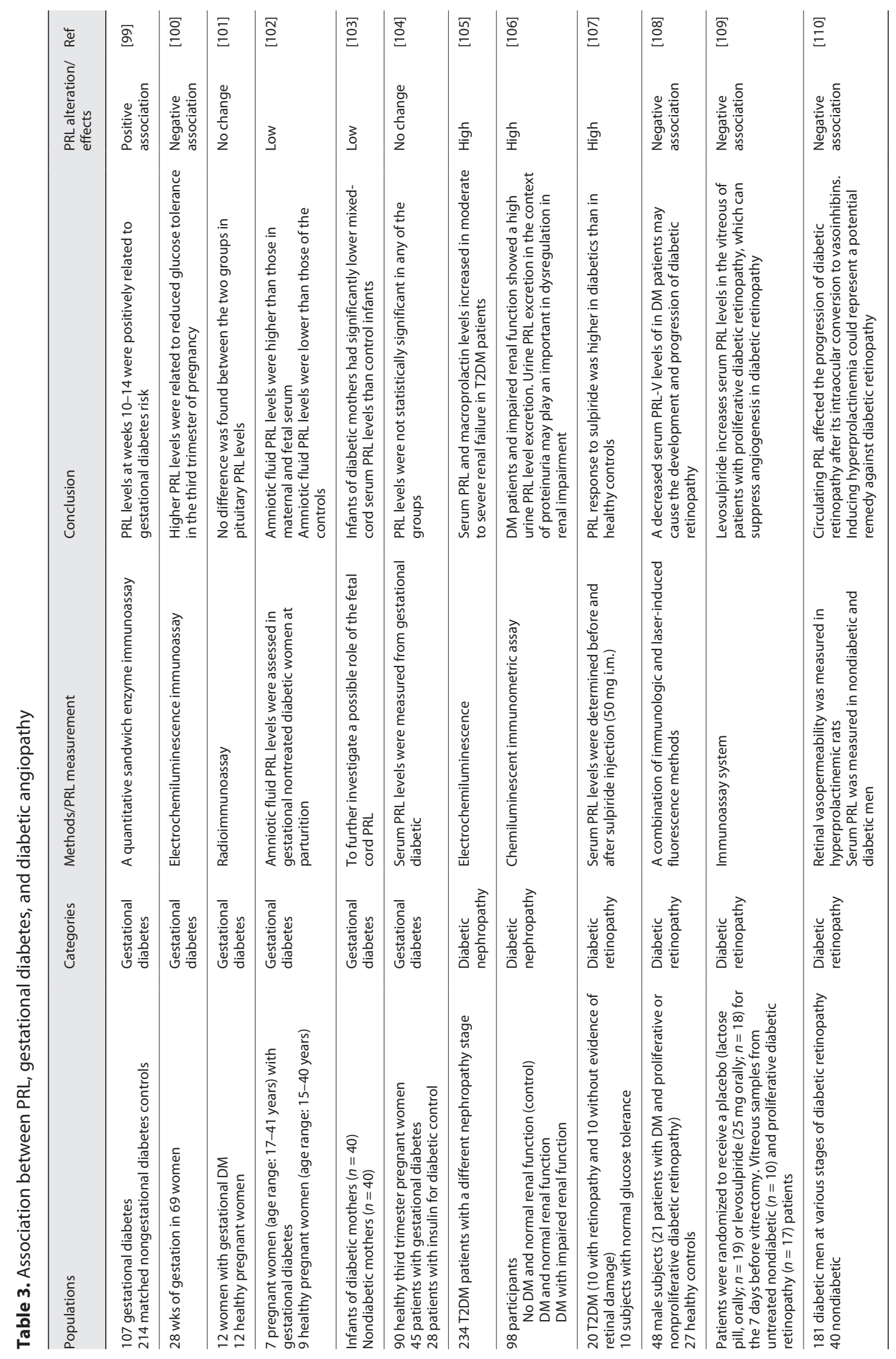


explain the association between PRL and diabetes, such as (1) PRL can stimulate expression of Pparg and Xbp1s, ADIPOQ, and glucose transporter 4 in visceral adipose tissue and increased circulating adiponectin levels, which can promote healthy adipose tissue function and systemic insulin sensitivity [75]; (2) the activation of protein kinase and phosphatidylinositol-3 kinase by PRL can modulate insulin sensitivity and islet density [118]; (3) PRL acts as an adipokine in downregulating fatty-acid synthase and lipoprotein lipase and regulating the bioactivities of leptin, interleukin-6, and adiponectin, which play an important role in the pathology of diabetes [54, 119]; (4) PRL, as an immunomodulator, may play an important role in the onset and development of T1D [26].

\section{PRL and Cognitive Impairment}

PRL is a multifunctional pleiotropic hormone in the brain. In lactating rats and PRL-treated ovariectomized animals, for example, PRL can protect the hippocampus from excitotoxicity $[120,121]$. PRL expression is regulated by the pituitary transcriptional factor-1, which is of critical importance to the production of PRL in the pituitary gland. Furthermore, the PRL regulatory elementbinding protein (Preb), which binds to and activates the PRL promoter in GH3 rat pituitary cells, is one of the key transcription factors controlling PRL. Our recent review literature and meta-analysis indicate that serum PRL levels in patients with Alzheimer's disease vary depending on the different conditions (e.g., stage of disease and treatment) $[7,122]$.

There is mounting evidence that PRL is believed to be a potential molecule for the treatment of cognitive impairment [7]. First, PRL can enhance memory, cognition, and learning abilities in vivo by several mechanisms because PRL regulates Drd2 gene expression [123, 124]. Second, several genes related to PRL-induced microglial activation such as Tac1, Adora2a, Drd2, Egr2, Car3, Hif3a, Sema3A, Notch, Ttr, Chat, Penk, and Penk may play essential roles in hippocampus neuroimmunomodulation or neuronal-cell protection $[7,124]$. Third, PRL can stimulate AKT (ak strain transforming/protein kinase B), resulting in GSK3 inactivation and tau phosphorylation inhibition in the female brain [125]. Fourth, neuroinflammation plays an important role in the pathogenesis of cognitive impairment [126]. In the CNS, PRL mediates both pro- and anti-inflammatory properties [7, 25]. As mentioned above, high concentrations of PRL may activate the signaling pathway via SOCS1 and 3, suppressing
T-bet activation [24]. PRL signaling via STAT3 promotes anti-inflammatory effects and IL-10 production in macrophages, suggesting that PRL signaling via STAT3 has antiapoptotic and proliferative properties [25, 127]. Taken together, PRL could potentially modulate neuro-inflammation to either prevent or delay the progression of cognitive impairment [7].

\section{Diabetes and Cognitive Impairment}

As has been described, there is a strong association between dementia risk and diabetes, including T1D, T2DM, and gestational diabetes. The symptoms and prognosis of diabetes-related cognitive impairment differ depending on the type of diabetes and age onset [128]. Consequently, we will describe the risk factors as well as the mechanism by which different types of diabetes participate in the pathology of cognitive impairment.

\section{T1D Mellitus and Cognitive Impairment}

The effectiveness of the cognitive functions (e.g., cognitive flexibility, information processing speed, intelligence, visual perception, visual and constant attention, and psychomotor efficiency) was lower in T1D patients than in nondiabetic controls [129]. Diabetes duration and $\mathrm{HbA1c}$ levels affected the severity of cognitive deficits in T1D patients [129-131]. A cohort study of 3,433 US adults aged $\geq 50$ years with T1D observed a significant association between HbAlc concentration and dementia risk. More specifically, adults with a majority of $\mathrm{HbAlc}$ exposure of 8-9\% had an increased risk of developing dementia, whereas adults with a majority of $\mathrm{HbAlc}$ exposure of 6-7.9\% had reduced risk [130].

There are several factors, such as hyperglycemia, hypoglycemia, diabetic ketoacidosis, and angiopathy, which were considered as potential predictors of cognitive function in T1D patients. T1DM patients commonly experience hyperglycemia, hypoglycemia, or both. Unfortunately, both hyperglycemia and hypoglycemia were found to be associated with cognitive changes. In $117 \mathrm{~T} 1 \mathrm{D}$ children aged 5-16 years, increased exposure to hyperglycemia can reduce verbal intelligence, but repeated hypoglycemia can diminish spatial intelligence and delayed recall. The effects of hypoglycemia and hyperglycemia on cognitive performance in T1D children are qualitatively distinct and are reliant in part on the exposure time during development, regardless of beginning age [132]. Another longitudinal study reported that hyperglycemia was related to decreased working memory, whereas hypoglyce- 
mia has been shown to have a negative impact on verbal ability, working memory, and nonverbal processing speed in 106 youth with T1D diagnosed 12 years previously [133]. Acute hyperglycemia (blood glucose levels $\geq 15 \mathrm{mmol} / \mathrm{L}$ ) in both T1D and T2DM adults is characterized by poor performance on psychomotor activities, increased subtraction errors, and slow mental subtraction speed [134]. T1D patients who have recurrent server hypoglycemia, on the other hand, have poorer cognitive performance than those who have never had severe hypoglycemia $[135,136]$. The cognitive abilities of young T1D patients aged 7-18 years with diabetic ketoacidosis are significantly lower than those of age-matched T1D patients without diabetic ketoacidosis [137, 138].

Microangiopathy (e.g., retinopathy and nephropathy) or macroangiopathy (e.g., myocardial infarction and stroke), or both, can occur in T1DM patients. In adults with T1DM, diabetic retinopathy is associated with a decline in intelligence, information processing, and attention/concentration abilities [139]. However, macrovascular complications, diabetes duration, proliferative retinopathy, and autonomic neuropathy can predict a decline in psychomotor speed in adult T1D patients [140].

\section{T2DM and Cognitive Impairment}

T2D has consistently been linked with a greater risk of dementia (e.g., vascular dementia, cognitive decline, mild cognitive impairment, and $\mathrm{AD}$ ). In a recent systematic review, the authors concluded that there was conclusive evidence based on 144 prospective studies to support the association between T2DM and dementia [141]. The level of cognitive dysfunction in T2DM patients can be loosely classified into three stages: mild cognitive impairment, dementia, and diabetes-related cognitive impairment [142].

The general picture that comes from the numerous studies on the risk factors for cognitive impairment in $\mathrm{T} 2 \mathrm{DM}$ is that there are numerous factors at play, each with very minor impacts. First, converging evidence shows chronically elevated glucose levels or HbA1c levels are related to cognitive decrements and dementia risk $[141,143]$ and second, vascular risk factors. Although the data are inconsistent despite a large amount of research, micro- or macrovascular disease, in particular hypertension and dyslipidemia, may be linked to cognitive impairment in T2DM patients [144]. Third, other risk factors for cognitive dysfunction in T2DM patients were identified as depression, insulin resistance, advanced glycation end products (AGEs), impaired neurogenesis, blood-brain barrier dysfunction, oxidative stress, and inflammation $[3,144-146]$.

\section{Gestational Diabetes Mellitus and Cognitive}

Impairment

High blood pressure and preeclampsia are well-known risks of gestational diabetes mellitus (GDM), but less attention has been paid to its impact on cognitive function. A cross-sectional study of 44 GDM patients and 45 normal pregnant women aged above 30 years observed cognitive impairment in GDM patients [147]. In a case-control study of 12 GDM patients and 28 healthy pregnant controls who experienced an oral glucose tolerance test (75 g), the authors observed that the GDM group had a longer auditory response latency than the healthy control group ( $296 \pm 82 \mathrm{~ms}$ vs. $206 \pm 74 \mathrm{~ms}$ ) after $60 \mathrm{~min}$ of testing, implying that the fetal neural activity of GDM mothers is slower than fetal healthy controls [148]. A systematic review and meta-analysis evaluated the cognitive performance of offspring from GDM mothers. Based on the 12 studies with 6,140 infants included, the authors found that offspring from GDM mothers had poorer scores for mental and psychomotor development, (a mean standardized difference for mental and psychomotor development were -0.41 and -0.31 , respectively), compared to offspring from healthy pregnant women [149].

Not only the mother but also the offspring are affected by GDM in terms of cognitive function. However, the effect on the offspring has been researched more than that on the mothers. Despite the fact that the complex pathophysiology of maternal cognitive impairment is unknown, it shares certain characteristics with T2DM [1]. On the other hand, there is mounting evidence that GDM can cause maternal cognitive impairment through neuroinflammation, insulin resistance, hyperglycemia, and oxidative stress [150-156].

\section{The Association between PRL, Diabetes, and Cognitive Impairment}

Insulin regulates a variety of biological processes by binding to and activating the insulin receptor and two closely related tyrosine kinase receptors [157]. Insulin receptors and their common downstream pathways are widely dispersed throughout the brain, and these pathways serve as regulators of brain function, neurogenesis, metabolism, and whole-body energy balance [158]. Several parts of the brain, such as the hippocampus, hypothalamus, cerebellum, cerebral cortex, olfactory bulb, and amygdala, contain the highest levels of insulin receptors [159]. Thus, insulin is believed to have neurotrophic and neuroprotective effects on CNS neurons because it has 
positive impacts on cognitive processes and emotions (e.g., executive functioning, attention, learning, and memory) [160].

After insulin binds to the insulin receptor, the receptor autophosphorylates, and the activated insulin receptor phosphorylates insulin receptor substrate (IRS) proteins, triggering the phosphatidylinositol 3-kinase/protein kinase B (PI3K/AKT) cascade, a crucial downstream pathway [157]. It is worth noting that the PRLR-S or PRLR-L isoform can also stimulate the PI3K/AKT signaling pathway activation [161].

Converging data have shown the important role of the $\mathrm{PI} 3 \mathrm{~K} / \mathrm{AKT}$ signaling pathway in neuroprotective mechanisms in the brain, especially in the hippocampus [162, 163]. For example, activation of the PI3K/AKT signaling pathway promotes neuronal survival by inhibiting cleavage of mitochondrial release of cytochrome c, Bcl-xL, ischemia-induced mitochondrial translocation of $\mathrm{BAD}$, and caspase activation $[164,165]$. AKT also inhibits GSK3 $\beta$, which has been linked with the pathogenesis of various neurodegenerative diseases [166].

In insulin resistance conditions, the insulin-signaling pathway is predominantly inactivated by serine phosphorylation of insulin receptor substance [167]. This process inhibits the PI3K/AKT signaling cascade, preventing glucose transporter 4 translocation, and lowering glucose absorption [168]. It is worth noting that GSK3 is also activated, resulting in tau hyperphosphorylation and amyloid- $\beta(A \beta)$ overexpression [169]. On the other hand, mitochondrial dysfunction is also recognized in cases of insulin resistance, causing oxidative stress [152]. Hyperglycemia causes an increase in the expression of pro-inflammatory cytokines due to the overproduction of AGEs and activation of the TREM1/DAP12 pathway $[170,171]$. Furthermore, free fatty acid causes pro-inflammatory cytokines by activating microglia via nuclear factor kappa $\beta$ (NF- $\kappa \mathrm{B}$ ) signaling. Thus, NF- $\kappa \beta$ was produced via binding of $A \beta$ with receptors of AGEs, worsening the inflammatory situation [172]. Inactivation of the insulin-signaling pathway, oxidative stress, and inflammation was considered as the common mechanisms for diabetes-induced cognitive impairment. However, in hyperglycemia, AGEs are overproduced, resulting in a reduction in cerebral blood flow. Cerebral flow dysfunction can contribute to cognitive failure by disrupting the blood-brain barrier transport system, which carries important substances (e.g., choline) into the brain and clearing unwanted compounds (e.g., A $\beta$ protein) [173].

In terms of the association of PRL with AKT signaling, PRL has a neuroprotective role in female rat neurodegen-

Interaction between Prolactin and

Diabetes in Neurodegeneration eration and inactivated GSK3 on Ser9 in W53 lymphoid cells, which was involved in PI3K/AKT/GSK3 pathway activation $[125,174]$. Following AKT-mediated phosphorylation of I $\mathrm{KB}$ kinase, PRL induces NF- $\kappa B$ activation, leading to survival gene activation (e.g., Bcl-2) [175]. During neuroprotection, PRL induces NF- $\mathrm{kB}$ activation against oxidative stress by overexpression of $\mathrm{p} 65$ and excitotoxicity in the hippocampus [176]. Several studies have found that PRL-induced NF- $\kappa \mathrm{B}$ activation is associated with an increase in protein content and activity of $\mathrm{Cu}^{2+} / \mathrm{Zn}^{2+} / \mathrm{Mn}^{2+}$-SOD enzymes $[177,178]$. Furthermore, activation of the PI3K/AKT pathway has a role in the regulation of glutathione synthesis [179]. High levels of PRL, as previously mentioned, can suppress T-bet activation by the signaling pathway activation through SOCS1 and 3 [24]. PRL signaling via STAT3 has both antiapoptotic and proliferative features $[25,127]$. Several genes related to microglial activation induced by PRL also play essential roles in hippocampus neuroimmunomodulation or neuronal-cell protection. Of note, PRL can improve memory, cognition, and learning ability by regulating Drd2 gene expression $[2,111]$.

We analyzed the TREM-1/DAP12 pathway and PRL, PRLR-S, PRLR-L, Preb, Pit-1, and pro-inflammatory cytokine mRNA levels in the hippocampus of diabetic mice and compared them to those measured in metformintreated diabetes mice and controls [180]. We discovered that the TREM-1 pathway (TREM-1, DAP12, and casp1), pro-inflammatory cytokines (Cox2, IL-1, and iNOS), Pit1 , and PRL expression levels were significantly increased in the hippocampus of diabetic mice, whereas these proinflammatory cytokines, as well as PRLR-S, PRLR-L, and Preb expression levels, were significantly decreased in diabetes mice treated with metformin. Furthermore, the levels of $\mathrm{p}$-Tau and GSK3 $\beta$ in the diabetic mice were significantly higher than those in the control mice and significantly lower than those in the diabetic mice treated with metformin.

Taken together, inflammation, oxidative stress, hyperglycemia, and insulin resistance are all factors that contribute to diabetes-induced cognitive impairment. PRL is neuroprotective, improves memory, cognition, and learning and has immunomodulatory and antioxidant properties. PRL can protect beta cells at physiological levels. Of note, PRL can improve glucose and HbA1C levels in diabetes patients. Although little is known about the relationship between PRL and diabetes in terms of cognitive dysfunction, the two share PI3K/AKT signaling pathways. However, it is critical to draw attention to it as a potential research topic for the future. To comprehend 


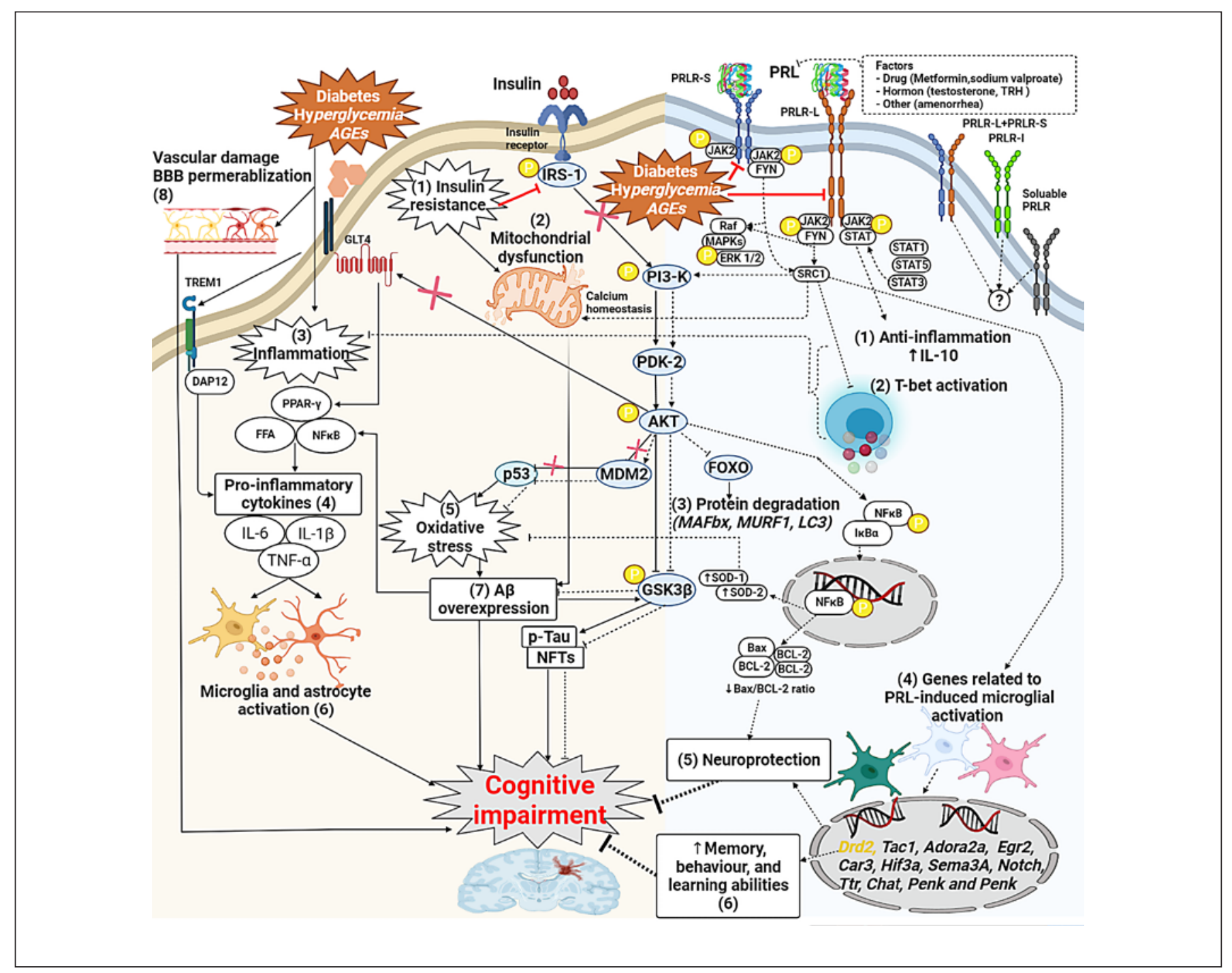

Fig. 1. Summary of the proposed association between cognitive impairment, diabetes, and PRL. The pink " $\mathrm{X}$ " shows inhibition or negative regulation. Solid and dashed arrows indicate for regulating in diabetes and PRL models, respectively. The left side of the figure showed eight mechanisms of diabetes (including T1D, type 2 diabetes, and gestational diabetes) induced cognitive impairment, which are insulin resistance, mitochondrial dysfunction, activation of pro-inflammatory cytokines, inflammation, oxidative stress, overexpression of $\mathrm{A} \beta$, vascular damage, and $\mathrm{BBB}$ permeabilization. The right side of the figure described six mechanisms by which PRL can protect cognitive impairment, which are anti-in-

the interacting molecular actions of PRL and diabetes in both pathological and physiological settings, an understanding of interaction signaling pathway activation between PRL and diabetes is required. Figure 1 is a summary of the proposed mechanisms of cognitive impairment associated with diabetes and PRL. flammation ability; inhibition of T-bet activation; inhibition of protein degradation; activation of genes related to PRL-induced microglia; enhancement of memory, behavior, and learning; and inhibition of apoptosis. BBB, blood-brain barrier; P, serine phosphorylation; IRS-1, insulin receptor substance; GLUT4, glucose transporter 4; FFA, free fatty acid; TNF- $\alpha$, tumor necrosis factor $\alpha$; IL-1 $\beta$, interleukin $1 \beta$; IL-6, interleukin 6 ; FOXO, forkhead box O; NFTs, neurofibrillary tangles; PRLR-I, prolactin receptor intermediate; SOD, superoxide dismutase gene; Bax, B-cell lymphoma protein 2-associated X.

\section{Conclusion}

Given the significant evidence for PRLs neuroprotective activities in the brain and the link between PRL and diabetes-induced cognitive impairment, the current review discussed how PRL and diabetes are linked to cogni- 
tive dysfunction. The PI3K/AKT pathway is now being studied, and it could be the most involved in the molecular mechanisms that explain how PRL and diabetes interact in cognitive impairment. Identifying whether the interaction of PRL and diabetes is specifically linked to the biological features of cognitive dysfunction, as well as determining whether the mechanisms linking diabetes and PRL to cognitive dysfunction can suggest novel strategies for cognitive dysfunction treatment, which have been difficult areas of research. However, these are potential study areas in the fields of diabetes, PRL, and dementia, which could assist in minimizing the incidence of cognitive decline and dementia in diabetic patients and the general public.

\section{Conflict of Interest Statement}

The authors have no conflict of interest to declare.

\section{Funding Sources} SCNU.

This work was supported by a research promotion program of

\section{Author Contributions}

H.D.N.: conceptualization, methodology, formal analysis, investigation, resources, data curation, writing - original draft, writing - review and editing, and visualization. M.S.K.: visualization, supervision, and project administration. H.Y.C.: visualization. B.P.Y.: visualization. H.O.: visualization. Ngoc Minh Hong Hoang: visualization. Won Hee Jo: visualization.

\section{Data Availability Statement}

The data supporting this review were obtained from cited studies.

\section{References}

1 John CM, Mohamed Yusof NIS, Abdul Aziz SH, Mohd Fauzi F. Maternal cognitive impairment associated with gestational diabetes mellitus: a review of potential contributing mechanisms. Int J Mol Sci. 2018;19(12):3894.

2 Li W, Huang E, Gao S. Type 1 diabetes mellitus and cognitive impairments: a systematic review. J Alzheimers Dis. 2017;57(1):29-36.

3 Geijselaers SLC, Sep SJS, Stehouwer CDA, Biessels GJ. Glucose regulation, cognition, and brain MRI in type 2 diabetes: a systematic review. Lancet Diabetes Endocrinol. 2015;3(1):75-89.

4 Prince M, Bryce R, Albanese E, Wimo A, Ribeiro W, Ferri CP. The global prevalence of dementia: a systematic review and metaanalysis. Alzheimers Dement. 2013;9(1):63-75. e2.

5 Khan MAB, Hashim MJ, King JK, Govender $\mathrm{RD}$, Mustafa H, Al Kaabi J. Epidemiology of type 2 diabetes: global burden of disease and forecasted trends. J Epidemiol Glob Health. 2020;10(1):107-11.

6 Faria de Castro L, Alves dos Santos Á, Augusto Casulari L, Ansaneli Naves L, Amorim Amato A. Association between variations of physiological prolactin serum levels and the risk of type 2 diabetes: a systematic review and meta-analysis. Diabetes Res Clin Pract. 2020; 166:108247.

7 Nguyen HD, Yu BP, Hoang NHM, Jo WH, Young Chung H, Kim MS. Prolactin and its altered action in Alzheimer's disease and Parkinson's disease. Neuroendocrinology. 2021. Epub ahead of print.

8 Shao S, Yao Z, Lu J, Song Y, He Z, Yu C, et al. Ablation of prolactin receptor increases hepatic triglyceride accumulation. Biochem Biophys Res Commun. 2018;498(3):693-9.
9 Wang T, Lu J, Xu Y, Li M, Sun J, Zhang J, et al. Circulating prolactin associates with diabetes and impaired glucose regulation: a population-based study. Diabetes Care. 2013; 36(7):1974-80.

10 Rasheed HA, Al-Kuraishy HM, Al-Gareeb AI, Hussien NR, Al-Nami MS. Effects of diabetic pharmacotherapy on prolactin hormone in patients with type 2 diabetes mellitus: bane or boon. J Adv Pharm Technol Res. 2019;10(4): 163-8.

11 Melnik BC. Milk signalling in the pathogenesis of type 2 diabetes. Med Hypotheses. 2011; 76(4):553-9.

12 Cejkova P, Fojtikova M, Cerna M. Immunomodulatory role of prolactin in diabetes development. Autoimmun Rev. 2009;9(1):237.

13 Janeway CA Jr, Travers P, Walport M, Shlomchik MJ. B-cell activation by armed helper $\mathrm{T}$ cells. Immunobiology: the immune system in health and disease. 5th ed. New York: Garland Science; 2001. Available from: https://www. ncbi.nlm.nih.gov/books/NBK27142/.

14 Hurst J, von Landenberg P. Toll-like receptors and autoimmunity. Autoimmun Rev. 2008;7(3):204-8.

15 Zipris D. Innate immunity and its role in type 1 diabetes. Curr Opin Endocrinol Diabetes Obes. 2008;15(4):326-31.

16 Borba VV, Zandman-Goddard G, Shoenfeld Y. Prolactin and autoimmunity. Front Immunol. 2018;9:73.

17 Montgomery DW, Krumenacker JS, Buckley AR. Prolactin stimulates phosphorylation of the human T-cell antigen receptor complex and ZAP-70 tyrosine kinase: a potential mechanism for its immunomodulation. Endocrinology. 1998;139(2):811-4.
18 Krumenacker JS, Montgomery DW, Buckley DJ, Gout PW, Buckley AR. Prolactin receptor signaling: shared components with the T-cell antigen receptor in Nb2 lymphoma cells. Endocrine. 1998;9(3):313-20.

19 Clevenger CV, Medaglia MV. The protein tyrosine kinase P59fyn is associated with prolactin (PRL) receptor and is activated by PRL stimulation of T-lymphocytes. Mol Endocrinol. 1994;8(6):674-81.

20 Takizawa K, Kitani S, Takeuchi F, Yamamoto K. Enhanced expression of CD69 and CD25 antigen on human peripheral blood mononuclear cells by prolactin. Endocr J. 2005; 52(5):635-41.

21 Ziegler SF, Ramsdell F, Alderson MR. The activation antigen CD69. Stem Cells. 1994; 12(5):456-65.

22 Orbach H, Shoenfeld Y. Hyperprolactinemia and autoimmune diseases. Autoimmun Rev. 2007;6(8):537-42.

23 Matalka KZ. Prolactin enhances production of interferon-gamma, interleukin-12, and interleukin-10, but not of tumor necrosis factor-alpha, in a stimulus-specific manner. $\mathrm{Cy}$ tokine. 2003;21(4):187-94.

24 Tomio A, Schust DJ, Kawana K, Yasugi T, Kawana Y, Mahalingaiah S, et al. Prolactin can modulate CD4+ T-cell response through receptor-mediated alterations in the expression of Tbet. Immunol Cell Biol. 2008;86(7):616-21.

25 Ramos-Martinez E, Ramos-Martínez I, Molina-Salinas G, Zepeda-Ruiz WA, Cerbon M. The role of prolactin in central nervous system inflammation. Rev Neurosci. 2021;32(3): 323-40.

26 Orbach H, Shoenfeld Y. Hyperprolactinemia and autoimmune diseases. Autoimmun Rev. 2007;6(8):537-42.
Interaction between Prolactin and

Diabetes in Neurodegeneration
Neuroendocrinology 2022;112:856-873 DOI: $10.1159 / 000521653$ 
27 Freemark M, Avril I, Fleenor D, Driscoll P, Petro A, Opara E, et al. Targeted deletion of the PRL receptor: effects on islet development, insulin production, and glucose tolerance. Endocrinology. 2002;143(4):1378-85.

28 Amaral ME, Cunha DA, Anhê GF, Ueno M, Carneiro EM, Velloso LA, et al. Participation of prolactin receptors and phosphatidylinositol 3-kinase and MAP kinase pathways in the increase in pancreatic islet mass and sensitivity to glucose during pregnancy. J Endocrinol. 2004;183(3):469-76.

29 Holstad M, Sandler S. Prolactin protects against diabetes induced by multiple low doses of streptozotocin in mice. J Endocrinol. 1999;163(2):229-34.

30 Lau J, Börjesson A, Holstad M, Sandler S. Prolactin regulation of the expression of TNFalpha, IFN-gamma and IL-10 by splenocytes in murine multiple low dose streptozotocin diabetes. Immunol Lett. 2006;102(1):25-30.

31 Kvasnickova H, Hampl R, Vondra K. DHEA, DHEAS and prolactin correlate with glucose control parameters in women of fertile age with type-1 diabetes mellitus. Physiol Res. 2015;64(Suppl 2):S255-8.

32 Orlická E, Vondra K, Hill M, Skibová J, Sterzl I, Zamrazil V. TRH test in patients with diabetes mellitus type 1 and/or autoimmune thyroiditis. Changes in the pituitary-thyroid axis, reverse T3, prolactin and growth hormone levels. Physiol Res. 2008;57 Suppl 1:S109-17.

33 Schmitz O. Absence of diurnal plasma prolactin rhythm in diabetic and non-diabetic uraemic patients. Acta Endocrinol. 1984;105(2): 173-8.

34 Ajlouni K, El-Khateeb M, El-Zaheri MM, ElNajdawi A. The response of growth hormone and prolactin to oral diazepam in diabetics. J Endocrinol Invest. 1982;5(3):157-9.

35 Perelygina AA, Golikova AA, Zin'ko NV. Levels of various pituitary and pancreatic hormones in the blood of patients with non-insulin-dependent diabetes mellitus. Probl Endokrinol. 1984;30(5):10-3.

36 Prelević GM, Würzburger MI, Perić LA. Blunted prolactin response to metoclopramide in insulin-dependent diabetic patients with secondary amenorrhoea. Arch Gynecol Obstet. 1987;241(3):145-9.

37 Salardi S, Fava A, Cassio A, Cicognani A, Tassoni P, Pirazzoli P, et al. Thyroid function and prolactin levels in insulin-dependent diabetic children and adolescents. Diabetes. 1984; 33(6):522-6.

38 Harrower AD. Growth hormone, prolactin and thyrotrophin responses to thyrotrophinreleasing hormone in diabetic patients. Postgrad Med J. 1980;56(657):481-4.

39 Botta RM, Donatelli M, Bucalo ML, Bellomonte ML, Bompiani GD. Placental lactogen, progesterone, total estriol and prolactin plasma levels in pregnant women with insulindependent diabetes mellitus. Eur J Obstet Gynecol Reprod Biol. 1984;16(6):393-401.

40 Jovanovic L, Peterson CM, Saxena BB, Dawood MY, Saudek CD. Feasibility of main- taining normal glucose profiles in insulin-dependent pregnant diabetic women. Am J Med. 1980;68(1):105-12.

41 Golikova AA. Effect of thyroliberin on the prolactin and thyrotropic and somatotropic hormone content of the blood plasma in insulin-dependent diabetes mellitus. Probl Endokrinol. 1982;28(5):25-9.

42 Iranmanesh A, Veldhuis JD, Carlsen EC, Vaccaro VA, Booth RA Jr, Lizarralde G, et al. Attenuated pulsatile release of prolactin in men with insulin-dependent diabetes mellitus. J Clin Endocrinol Metab. 1990; 71(1):73-8

43 Zukowska-Szczechowska E, Moczulski D, Grzeszczak W, Gumprecht J. Prolactin secretion in diabetic nephropathy of patients with diabetes mellitus type I (IDDM). Pol Arch Med Wewn. 1996;95(2):125-34.

44 Gnudi A, Lugari R, Cavazzini MG. Variation of blood glucose and serum growth hormone, prolactin and insulin in subjects with insulindependent diabetes, after OGTT and pretreatment with 2-Br-alpha-ergocryptine. Acta Diabetol Lat. 1977;14(3-4):119-28.

45 Perimenis $\mathrm{P}$, Bouckenooghe T, Delplanque J, Moitrot E, Eury E, Lobbens S, et al. Placental antiangiogenic prolactin fragments are increased in human and rat maternal diabetes. Biochim Biophys Acta. 2014;1842(9):178393.

46 Fourcade G, Colombo BM, Grégoire S, Baeyens A, Rachdi L, Guez F, et al. Fetal pancreas transplants are dependent on prolactin for their development and prevent type 1 diabetes in syngeneic but not allogeneic mice. Diabetes. 2013;62(5):1646-55.

47 Johansson M, Olerud J, Jansson L, Carlsson P-O. Prolactin treatment improves engraftment and function of transplanted pancreatic islets. Endocrinology. 2009;150(4):1646-53.

48 Hyslop CM, Tsai S, Shrivastava V, Santamaria $\mathrm{P}$, Huang C. Prolactin as an adjunct for type 1 diabetes immunotherapy. Endocrinology. 2016;157(1):150-65.

49 Johnston DG, Alberti KG, Nattrass M, Burrin JM, Blesa-Malpica G, Hall K, et al. Hyperinsulinaemia in hyperprolactinaemic women. Clin Endocrinol. 1980;13(4):361-8.

50 Schernthaner G, Prager R, Punzengruber C, Luger A. Severe hyperprolactinaemia is associated with decreased insulin binding in vitro and insulin resistance in vivo. Diabetologia. 1985;28(3):138-42.

51 Gulcelik NE, Usman A. Macroprolactinaemia in diabetic patients. Neuro Endocrinol Lett. 2010;31(2):270-4.

52 Zhang XZ, Imachi H, Lyu JY, Fukunaga K, Sato S, Ibata T, et al. Prolactin regulatory element-binding protein is involved in suppression of the adiponectin gene in vivo. J Endocrinol Invest. 2017;40(4):437-45.

53 Greenman Y, Tordjman K, Stern N. Increased body weight associated with prolactin secreting pituitary adenomas: weight loss with normalization of prolactin levels. Clin Endocrinol. 1998;48(5):547-53.
54 Nilsson L, Binart N, Bohlooly YM, Bramnert M, Egecioglu E, Kindblom J, et al. Prolactin and growth hormone regulate adiponectin secretion and receptor expression in adipose tissue. Biochem Biophys Res Commun. 2005; 331(4):1120-6

55 Pala NA, Laway BA, Misgar RA, Shah ZA, Gojwari TA, Dar TA. Profile of leptin, adiponectin, and body fat in patients with hyperprolactinemia: response to treatment with cabergoline. Indian J Endocrinol Metab. 2016;20(2): $177-81$

56 Zhou W, Wahl DR. Metabolic abnormalities in glioblastoma and metabolic strategies to overcome treatment resistance. Cancers. 2019;11(9):1231.

57 Vakov L. Basal prolactin secretion in diabetes mellitus. Vutr Boles. 1979;18(5):54-63.

58 Yamamoto T, Ricordi C, Mita A, Miki A, Sakuma Y, Molano RD, et al. Beta-cell specific cytoprotection by prolactin on human islets. Transplant Proc. 2008;40(2):382-3.

59 Terra LF, Garay-Malpartida MH, Wailemann RA, Sogayar MC, Labriola L. Recombinant human prolactin promotes human beta cell survival via inhibition of extrinsic and intrinsic apoptosis pathways. Diabetologia. 2011; 54(6):1388-97.

60 Weinhaus AJ, Stout LE, Sorenson RL. Glucokinase, hexokinase, glucose transporter 2, and glucose metabolism in islets during pregnancy and prolactin-treated islets in vitro: mechanisms for long term up-regulation of islets. Endocrinology. 1996;137(5):1640-9.

61 Park S, Kim DS, Daily JW, Kim SH. Serum prolactin concentrations determine whether they improve or impair $\beta$-cell function and insulin sensitivity in diabetic rats. Diabetes Metab Res Rev. 2011;27(6):564-74.

62 Therkelsen KE, Abraham TM, Pedley A, Massaro JM, Sutherland P, Hoffmann U, et al. Association between prolactin and incidence of cardiovascular risk factors in the framingham heart study. J Am Heart Assoc. 2016;5(2): e002640.

63 Dutka R, Chmyr N, Svitlyk H, Leontieva Z. Prolactin, cortisol, free thyroxine and thyroidstimulating hormone: markers of staging of metabolic syndrome as a risk factor of coronary artery disease and type 2 diabetes mellitus. Georgian Med News. 2019;(297):80-3.

64 Daimon M, Kamba A, Murakami H, Mizushiri S, Osonoi S, Yamaichi M, et al. Association between serum prolactin levels and insulin resistance in non-diabetic men. PLoS One. 2017;12(4): e0175204.

65 Krysiak R, Szkróbka W, Okopień B. Sex-dependent effect of metformin on serum prolactin levels in hyperprolactinemic patients with type 2 diabetes: a pilot study. Exp Clin Endocrinol Diabetes. 2018;126(6):342-8.

66 Krysiak R, Okrzesik J, Okopien B. The effect of short-term metformin treatment on plasma prolactin levels in bromocriptine-treated patients with hyperprolactinaemia and impaired glucose tolerance: a pilot study. Endocrine. 2015;49(1):242-9. 
67 Al-Nami MS, Al-Kuraishy HM, Al-Gareeb AI, Al-Mamoori F. Metabolic profile and prolactin serum levels in men with type 2 diabetes mellitus: old-new rubric. Int J Crit Illn Inj Sci. 2019;9(3):120-6.

68 Wang T, Lu J, Xu Y, Li M, Sun J, Zhang J, et al. Circulating prolactin associates with diabetes and impaired glucose regulation: a population-based study. Diabetes Care. 2013; 36(7):1974-80.

69 Balbach L, Wallaschofski H, Völzke H, Nauck M, Dörr M, Haring R. Serum prolactin concentrations as risk factor of metabolic syndrome or type 2 diabetes? BMC Endocr Disord. 2013;13:12.

70 Wang T, Xu Y, Xu M, Ning G, Lu J, Dai M, et al. Circulating prolactin and risk of type $2 \mathrm{di}$ abetes: a prospective study. Am J Epidemiol. 2016;184(4):295-301.

71 Chahar C, Chahar K, Ankit BS, Gadhwal A, Agrawal RP. Association of serum prolactin level with impaired glucose regulation and diabetes. J Assoc Physicians India. 2017;65(3): 34-9.

72 Li J, Rice MS, Huang T, Hankinson SE, Clevenger CV, Hu FB, et al. Circulating prolactin concentrations and risk of type 2 diabetes in US women. Diabetologia. 2018;61(12):2549_ 60.

73 Manshaei N, Shakibaei F, Fazilati M, Salavati $\mathrm{H}$, Negahdary M, Palizban A. An investigation of the association between the level of prolactin in serum and type II diabetes. Diabetes Metab Syndr. 2019;13(5):3035-41.

74 Ozisik H, Suner A, Cetinkalp S. Prolactin effect on blood glucose and insülin in breastfeeding women. Diabetes Metab Syndr. 2019; 13(3):1765-7.

75 Ruiz-Herrera X, de los Ríos EA, Díaz JM, Lerma-Alvarado RM, Martínez de la Escalera L, López-Barrera F, et al. Prolactin promotes adipose tissue fitness and insulin sensitivity in obese males. Endocrinology. 2016;158(1):5668.

76 Golikova AA. Somatotropin and prolactin levels in patients with insulin-dependent diabetes mellitus. Probl Endokrinol. 1984;30(1): 8-11.

77 Drejer J, Hendriksen C, Nielsen LM, Binder C, Hagen C, Kehlet H. Diurnal variations in plasma prolactin, growth hormone, cortisol and blood glucose in labile diabetes mellitus. Clin Endocrinol. 1977;6(1):57-64.

78 Mooradian AD, Morley JE, Billington CJ, Slag MF, Elson MK, Shafer RB. Hyperprolactinaemia in male diabetics. Postgrad Med J. 1985; 61(711):11-4.

79 Gragnoli G, Tanganelli I, Signorini AM. Prolactin response to TRH in insulin-dependent diabetes mellitus. Boll Soc Ital Biol Sper. 1980; 56(19):1989-95.

80 Lester E, Woodroffe FJ, Smith RL. Prolactin and impotence in diabetes mellitus. Ann Clin Biochem. 1981;18(1):54-9.
81 Krysiak R, Szkróbka W, Okopień B. The effect of metformin on serum gonadotropin levels in postmenopausal women with diabetes and prediabetes: a pilot study. Exp Clin Endocrinol Diabetes. 2018;126(10):645-50.

82 Washburne AC. Nicotinic acid in the treatment of certain depressed states: a preliminary report. Ann Intern Med. 1950;32(2):261-9.

83 Djursing H, Nyholm HC, Hagen C, MølstedPedersen L. Depressed prolactin levels in diabetic women with anovulation. Acta Obstet Gynecol Scand. 1982;61(5):403-6.

84 Coiro V, Davoli C, Volpi R, Sorini E, Voltini E, Rossi G, et al. The GABAergic control of prolactin release is not affected by insulin-dependent diabetes mellitus: evidence from studies with sodium valproate. Acta Diabetol Lat. 1986;23(1):51-5.

85 El-Eshmawy MM, Elkhamisy EM, Elsayed E, Kamal S. Impact of gender on the association between low serum prolactin and left ventricular mass in subjects with prediabetes. Diabetes Metab J. 2017;41(3):195-204.

86 Krysiak R, Kowalcze K, Szkrobka W, Okopien $B$. The effect of metformin on prolactin levels in patients with drug-induced hyperprolactinemia. Eur J Intern Med. 2016;30:94-8.

87 Kumari TM, Govindarajulu P. Hyperglycemic effect of prolactin in anterior pituitary transplanted rats. Endocrinol Jpn. 1990;37(6): $819-25$.

88 Furigo IC, Suzuki MF, Oliveira JE, RamosLobo AM, Teixeira PDS, Pedroso JA, et al. Suppression of prolactin secretion partially explains the antidiabetic effect of bromocriptine in ob/ob mice. Endocrinology. 2018; 160(1):193-204.

89 Hawkins TA, Gala RR, Dunbar JC. Prolactin modulates the incidence of diabetes in male and female NOD mice. Autoimmunity. 1994; 18(3):155-62.

90 Park S, Kang S, Lee HW, Ko BS. Central prolactin modulates insulin sensitivity and insulin secretion in diabetic rats. Neuroendocrinology. 2012;95(4):332-43.

91 Yogev L, Gottriech A, Timan B, Homonnai ZT, Paz GF. Changes in LH and prolactin levels in diabetic male rats and the role of the opiate system in the control of their secretion. Life Sci. 1985;37(11):993-9.

92 Lemini M, Ruiz-Herrera X, Ledesma-Colunga MG, Díaz-Lezama N, De Los Ríos EA, López-Barrera F, et al. Prolactin anterior pituitary expression and circulating levels are reduced in obese and diabetic rats: role of TGF- $\beta$ and TNF- $\alpha$. Am J Physiol Regul Integr Comp Physiol. 2015;308(9):R792-9.

93 Mera T, Fujihara H, Saito J, Kawasaki M, Hashimoto H, Saito T, et al. Downregulation of prolactin-releasing peptide gene expression in the hypothalamus and brainstem of diabetic rats. Peptides. 2007;28(8):1596-604.

94 Ernst A, Sharma AN, Elased KM, Guest PC, Rahmoune H, Bahn S. Diabetic db/db mice exhibit central nervous system and peripheral molecular alterations as seen in neurological disorders. Transl Psychiatry. 2013;3(5):e263.
95 Voogt JL, Lee Y, Yang S, Arbogast L. Chapter 12 regulation of prolactin secretion during pregnancy and lactation. Progress in brain research. Elsevier; 2001. Vol. 133; p. 173-85.

96 Retnakaran R, Ye C, Kramer CK, Connelly PW, Hanley AJ, Sermer M, et al. Maternal serum prolactin and prediction of postpartum $\beta$-cell function and risk of prediabetes/ diabetes. Diabetes Care. 2016;39(7):1250-8.

97 Banerjee RR, Cyphert HA, Walker EM, Chakravarthy H, Peiris H, Gu X, et al. Gestational diabetes mellitus from inactivation of prolactin receptor and $\mathrm{MafB}$ in islet $\beta$-cells. Diabetes. 2016;65(8):2331-41.

98 Huang C, Snider F, Cross JC. Prolactin receptor is required for normal glucose homeostasis and modulation of beta-cell mass during pregnancy. Endocrinology. 2009; 150(4):1618-26

99 Li M, Song Y, Rawal S, Hinkle SN, Zhu Y, Tekola-Ayele F, et al. Plasma prolactin and progesterone levels and the risk of gestational diabetes: a prospective and longitudinal study in a multiracial cohort. Front Endocrinol. 2020;11:83.

100 Ekinci EI, Torkamani N, Ramchand SK, Churilov L, Sikaris KA, Lu ZX, et al. Higher maternal serum prolactin levels are associated with reduced glucose tolerance during pregnancy. J Diabetes Investig. 2017;8(5): 697-700.

101 Luthman M, Stock S, Werner S, Bremme K. Growth hormone-binding protein in plasma is inversely correlated to placental lactogen and augmented with increasing body mass index in healthy pregnant women and women with gestational diabetes mellitus. Gynecol Obstet Invest. 1994;38(3):145-50.

102 Botta RM, Donatelli M, Zampardi A, Incandela T, Valenza P, Albano V, et al. Study on maternal, fetal and amniotic prolactin in gestational diabetic women, at term. Acta Diabetol Lat. 1982;19(3):275-80.

103 Saltzman DH, Barbieri RL, Frigoletto FD Jr Decreased fetal cord prolactin concentration in diabetic pregnancies. Am J Obstet Gynecol. 1986;154(5):1035-8.

104 Fadel HE, Saad SA, Davis H, Nelson GH. Fetal lung maturity in diabetic pregnancies: relation among amniotic fluid insulin, prolactin, and lecithin. Am J Obstet Gynecol. 1988; 159(2):457-63.

105 Sari F, Sari R, Ozdem S, Sarikaya M, Cetinkaya R. Serum prolactin and macroprolactin levels in diabetic nephropathy. Clin Nephrol. 2012;78(1):33-9.

106 Triebel J, Moreno-Vega AI, Vázquez-Membrillo M, Nava G, García-Franco R, LópezStar E, et al. High prolactin excretion in patients with diabetes mellitus and impaired renal function. Clin Lab. 2015;61(7):709-16.

107 Verrillo A, de Teresa A, Martino C, di Chiara G. Prolactin response to sulpiride in non insulin dependent diabetes mellitus. Boll Soc Ital Biol Sper. 1985;61(2):183-8.
Interaction between Prolactin and

Diabetes in Neurodegeneration
Neuroendocrinology 2022;112:856-873 DOI: $10.1159 / 000521653$ 
108 Triebel J, Huefner M, Ramadori G. Investigation of prolactin-related vasoinhibin in sera from patients with diabetic retinopathy. Eur J Endocrinol. 2009;161(2):345-53.

109 Nuñez-Amaro CD, Moreno-Vega AI, Adan-Castro E, Zamora M, Garcia-Franco R, Ramirez-Neria P, et al. Levosulpiride increases the levels of prolactin and antiangiogenic vasoinhibin in the vitreous of patients with proliferative diabetic retinopathy. Transl Vis Sci Technol. 2020;9(9):27.

110 Arnold E, Rivera JC, Thebault S, MorenoPáramo D, Quiroz-Mercado H, QuintanarStéphano A, et al. High levels of serum prolactin protect against diabetic retinopathy by increasing ocular vasoinhibins. Diabetes. 2010;59(12):3192-7.

111 Clapp C, Thebault S, Macotela Y, MorenoCarranza B, Triebel J, Martínez de la Escalera G. Regulation of blood vessels by prolactin and vasoinhibins. Adv Exp Med Biol. 2015;846:83-95.

112 Krysiak R, Szkróbka W, Okopień B. Effect of metformin on hypothalamic-pituitary-thyroid axis activity in elderly antipsychotictreated women with type 2 diabetes and subclinical hypothyroidism: a preliminary study. J Clin Pharmacol. 2018;58(5):586-92.

113 Baxter RC, Bryson JM, Turtle JR. Changes in rat liver prolactin binding sites in diabetes are sex dependent. Metabolism. 1981;30(3): 211-6.

114 Angeli A, Ramenghi U, Del Bello S, Gaidano G, Cerutti F, Baratono S. Increased plasma corticosteroid-binding globulin in insulindependent pubertal diabetics: relationships with other glycoproteins, growth hormone and prolactin. Acta Diabetol Lat. 1979;16(4): 295-304.

115 LaPensee CR, Horseman ND, Tso P, Brandebourg TD, Hugo ER, Ben-Jonathan N. The prolactin-deficient mouse has an unaltered metabolic phenotype. Endocrinology. 2006; 147(10):4638-45.

116 Lyons DJ, Hellysaz A, Broberger C. Prolactin regulates tuberoinfundibular dopamine neuron discharge pattern: novel feedback control mechanisms in the lactotrophic axis. J Neurosci. 2012;32(23):8074-83.

117 Ruiz-Herrera X, de Los Ríos EA, Díaz JM, Lerma-Alvarado RM, Martínez de la Escalera L, López-Barrera F, et al. Prolactin promotes adipose tissue fitness and insulin sensitivity in obese males. Endocrinology. 2017; 158(1):56-68.

118 Yu J, Xiao F, Zhang Q, Liu B, Guo Y, Lv Z, et al. PRLR regulates hepatic insulin sensitivity in mice via STAT5. Diabetes. 2013;62(9): 3103-13.

119 Ling C, Svensson L, Odén B, Weijdegård B, Edén B, Edén $S$, et al. Identification of functional prolactin (PRL) receptor gene expression: PRL inhibits lipoprotein lipase activity in human white adipose tissue. J Clin Endocrinol Metab. 2003;88(4):1804-8.

120 Rivero-Segura NA, Flores-Soto E, García de la Cadena S, Coronado-Mares I, Gomez-
Verjan JC, Ferreira DG, et al. Prolactin-induced neuroprotection against glutamate excitotoxicity is mediated by the reduction of $[\mathrm{Ca} 2+]$ i overload and NF- $\kappa \mathrm{B}$ activation. PLoS One. 2017;12(5):e0176910.

121 Vergara-Castañeda E, Grattan DR, Pasantes-Morales $\mathrm{H}$, Pérez-Domínguez M, Cabrera-Reyes EA, Morales T, et al. Prolactin mediates neuroprotection against excitotoxicity in primary cell cultures of hippocampal neurons via its receptor. Brain Res. 2016; 1636:193-9.

122 Duc Nguyen H, Hoang NMH, Ko M, Seo D, Kim S, Jo WH, et al. Association between serum prolactin levels and neurodegenerative diseases: systematic review and meta-analysis. Neuroimmunomodulation. 2021:1-12. Epub ahead of print.

123 Walker TL, Vukovic J, Koudijs MM, Blackmore DG, Mackay EW, Sykes AM, et al. Prolactin stimulates precursor cells in the adult mouse hippocampus. PLoS One. 2012;7(9): e44371.

124 Cabrera-Reyes EA, Vanoye-Carlo A, Rodríguez-Dorantes M, Vázquez-Martínez ER, Rivero-Segura NA, Collazo-Navarrete O, et al. Transcriptomic analysis reveals new hippocampal gene networks induced by prolactin. Sci Rep. 2019;9(1):13765.

125 Muñoz-Mayorga D, Guerra-Araiza C, Torner L, Morales T. Tau phosphorylation in female neurodegeneration: role of estrogens, progesterone, and prolactin. Front Endocrinol. 2018;9:133.

126 Leng F, Edison P. Neuroinflammation and microglial activation in Alzheimer disease: where do we go from here? Nat Rev Neurol. 2021;17(3):157-72.

127 Williams LM, Sarma U, Willets K, Smallie T, Brennan F, Foxwell BM. Expression of constitutively active STAT3 can replicate the cytokine-suppressive activity of interleukin-10 in human primary macrophages. J Biol Chem. 2007;282(10):6965-75.

128 Biessels GJ, Deary IJ, Ryan CM. Cognition and diabetes: a lifespan perspective. Lancet Neurol. 2008;7(2):184-90.

129 Brands AM, Biessels GJ, de Haan EH, Kappelle LJ, Kessels RP. The effects of type 1 diabetes on cognitive performance: a metaanalysis. Diabetes Care. 2005;28(3):72635.

130 Lacy ME, Gilsanz P, Karter AJ, Quesenberry CP, Pletcher MJ, Whitmer RA. Long-term glycemic control and dementia risk in type 1 diabetes. Diabetes Care. 2018;41(11):233945.

131 Ferguson SC, Blane A, Wardlaw J, Frier BM, Perros P, McCrimmon RJ, et al. Influence of an early-onset age of type 1 diabetes on cerebral structure and cognitive function. Diabetes Care. 2005;28(6):1431-7.

132 Perantie DC, Lim A, Wu J, Weaver P, Warren SL, Sadler M, et al. Effects of prior hypoglycemia and hyperglycemia on cognition in children with type 1 diabetes mellitus. Pediatr Diabetes. 2008;9(2):87-95.
133 Lin A, Northam EA, Rankins D, Werther GA, Cameron FJ. Neuropsychological profiles of young people with type 1 diabetes 12 yr after disease onset. Pediatr Diabetes. 2010; 11(4):235-43.

134 Cox DJ, Kovatchev BP, Gonder-Frederick LA, Summers KH, McCall A, Grimm KJ, et al. Relationships between hyperglycemia and cognitive performance among adults with type 1 and type 2 diabetes. Diabetes Care. 2005;28(1):71-7.

135 Langan SJ, Deary IJ, Hepburn DA, Frier BM. Cumulative cognitive impairment following recurrent severe hypoglycaemia in adult patients with insulin-treated diabetes mellitus. Diabetologia. 1991;34(5):337-44.

136 Wredling R, Levander S, Adamson U, Lins PE. Permanent neuropsychological impairment after recurrent episodes of severe hypoglycaemia in man. Diabetologia. 1990; 33(3):152-7.

137 Jessup AB, Grimley MB, Meyer E, Passmore GP, Belger A, Hoffman WH, et al. Effects of diabetic ketoacidosis on visual and verbal neurocognitive function in young patients presenting with new-onset type 1 diabetes. J Clin Res Pediatr Endocrinol. 2015;7(3):20310 .

138 Semenkovich K, Bischoff A, Doty T, Nelson S, Siller AF, Hershey T, et al. Clinical presentation and memory function in youth with type 1 diabetes. Pediatr Diabetes. 2016; 17(7):492-9.

139 Ferguson SC, Blane A, Perros P, McCrimmon RJ, Best JJ, Wardlaw J, et al. Cognitive ability and brain structure in type 1 diabetes: relation to microangiopathy and preceding severe hypoglycemia. Diabetes. 2003;52(1): $149-56$.

140 Ryan CM, Geckle MO, Orchard TJ. Cognitive efficiency declines over time in adults with type 1 diabetes: effects of micro- and macrovascular complications. Diabetologia. 2003;46(7):940-8.

141 Xue M, Xu W, Ou YN, Cao XP, Tan MS, Tan $\mathrm{L}$, et al. Diabetes mellitus and risks of cognitive impairment and dementia: a systematic review and meta-analysis of 144 prospective studies. Ageing Res Rev. 2019;55:100944.

142 Koekkoek PS, Kappelle LJ, van den Berg E, Rutten GE, Biessels GJ. Cognitive function in patients with diabetes mellitus: guidance for daily care. Lancet Neurol. 2015;14(3): 329-40.

143 Rawlings AM, Sharrett AR, Mosley TH, Ballew SH, Deal JA, Selvin E. Glucose peaks and the risk of dementia and 20-year cognitive decline. Diabetes Care. 2017;40(7):879_ 86.

144 Feinkohl I, Price JF, Strachan MW, Frier $\mathrm{BM}$. The impact of diabetes on cognitive decline: potential vascular, metabolic, and psychosocial risk factors. Alzheimers Res Ther. 2015;7(1):46.

145 Whitmer RA. Type 2 diabetes and risk of cognitive impairment and dementia. Curr Neurol Neurosci Rep. 2007;7(5):373-80. 
146 Cholerton B, Baker LD, Montine TJ, Craft S. Type 2 diabetes, cognition, and dementia in older adults: toward a precision health approach. Diabetes Spectr. 2016;29(4):210-9.

147 Keskin FE, Ozyazar M, Pala AS, Elmali AD, Yilmaz B, Uygunoglu U, et al. Evaluation of cognitive functions in gestational diabetes mellitus. Exp Clin Endocrinol Diabetes. 2015;123(4):246-51.

148 Linder K, Schleger F, Kiefer-Schmidt I, Fritsche L, Kümmel S, Heni M, et al. Gestational diabetes impairs human fetal postprandial brain activity. J Clin Endocrinol Metab. 2015;100(11):4029-36.

149 Camprubi Robles M, Campoy C, Garcia Fernandez L, Lopez-Pedrosa JM, Rueda R, Martin MJ. Maternal diabetes and cognitive performance in the offspring: a systematic review and meta-analysis. PLoS One. 2015; 10(11):e0142583.

150 Buchanan TA, Xiang AH. Gestational diabetes mellitus. J Clin Invest. 2005;115(3):485-91.

151 Diehl T, Mullins R, Kapogiannis D. Insulin resistance in Alzheimer's disease. Transl Res. 2017;183:26-40.

152 Butterfield DA, Di Domenico F, Barone E. Elevated risk of type 2 diabetes for development of Alzheimer disease: a key role for oxidative stress in brain. Biochim Biophys Acta. 2014;1842(9):1693-706.

153 Genc S, Kusku-Kiraz Z, Dervisoglu E, Oztop N, Dinccag N, Gurdol FJCI. The relation of oxidative stress biomarkers with proinflammatory cytokines in gestational diabetes. Clin Investig. 2017;7:44-8.

154 Li H, Yin Q, Li N, Ouyang Z, Zhong M. Plasma markers of oxidative stress in patients with gestational diabetes mellitus in the second and third trimester. Obstet Gynecol Int. 2016;2016:3865454.

155 Gueuvoghlanian-Silva BY, Torloni MR, Mattar R, de Oliveira LS, Scomparini FB, Nakamura MU, et al. Profile of inflammatory mediators in gestational diabetes mellitus: phenotype and genotype. Am J Reprod. 2012;67(3):241-50.

156 Korkmazer E, Solak N. Correlation between inflammatory markers and insulin resistance in pregnancy. J Obstet Gynaecol. 2015; 35(2):142-5.

157 Vigneri R, Goldfine ID, Frittitta L. Insulin, insulin receptors, and cancer. J Endocrinol Invest. 2016;39(12):1365-76.

158 Kleinridders A, Ferris HA, Cai W, Kahn CR. Insulin action in brain regulates systemic metabolism and brain function. Diabetes. 2014;63(7):2232-43.

159 Derakhshan F, Toth C. Insulin and the brain. Curr Diabetes Rev. 2013;9(2):102-16.
160 Akintola AA, van Heemst D. Insulin, aging, and the brain: mechanisms and implications. Front Endocrinol. 2015;6:13.

161 Molina-Salinas G, Rivero-Segura NA, Cabrera-Reyes EA, Rodríguez-Chávez $\mathrm{V}$, Langley E, Cerbon M. Decoding signaling pathways involved in prolactin-induced neuroprotection: a review. Front Neuroendocrinol. 2021;61:100913.

162 Constantino LC, Binder LB, Vandresen-Filho S, Viola GG, Ludka FK, Lopes MW, et al. Role of phosphatidylinositol-3 kinase pathway in NMDA preconditioning: different mechanisms for seizures and hippocampal neuronal degeneration induced by quinolinic acid. Neurotox Res. 2018;34(3):452-62.

163 Dong Y, Pu K, Duan W, Chen H, Chen L, Wang Y. Involvement of Akt/CREB signaling pathways in the protective effect of EPA against interleukin- $1 \beta$-induced cytotoxicity and BDNF down-regulation in cultured rat hippocampal neurons. BMC Neurosci. 2018;19(1):52.

164 Bhuiyan MI, Jung SY, Kim HJ, Lee YS, Jin C. Major role of the PI3K/Akt pathway in ischemic tolerance induced by sublethal oxygen-glucose deprivation in cortical neurons in vitro. Arch Pharm Res. 2011;34(6):102334.

165 Miyawaki T, Mashiko T, Ofengeim D, Flannery RJ, Noh K-M, Fujisawa S, et al. Ischemic preconditioning blocks $\mathrm{BAD}$ translocation, Bcl-xL cleavage, and large channel activity in mitochondria of postischemic hippocampal neurons. Proc Natl Acad Sci U S A. 2008;105(12):4892-7.

166 Hu YS, Long N, Pigino G, Brady ST, Lazarov O. Molecular mechanisms of environmental enrichment: impairments in Akt/GSK3 $\beta$, neurotrophin- 3 and CREB signaling. PLOS One. 2013;8(5):e64460.

167 Talbot K, Wang HY, Kazi H, Han LY, Bakshi KP, Stucky A, et al. Demonstrated brain insulin resistance in Alzheimer's disease patients is associated with IGF-1 resistance, IRS-1 dysregulation, and cognitive decline. J Clin Invest. 2012;122(4):1316-38.

168 Saltiel AR, Kahn CR. Insulin signalling and the regulation of glucose and lipid metabolism. Nature. 2001;414(6865):799-806.

169 Salcedo-Tello P, Ortiz-Matamoros A, Arias C. GSK3 function in the brain during development, neuronal plasticity, and neurodegeneration. Int J Alzheimers Dis. 2011;2011: 189728.

170 Spauwen PJ, van Eupen MG, Köhler S, Stehouwer CD, Verhey FR, van der Kallen CJ, et al. Associations of advanced glycation end-products with cognitive functions in in- dividuals with and without type 2 diabetes: the maastricht study. J Clin Endocrinol Metab. 2015;100(3):951-60.

171 Thorsen SU, Pipper CB, Mortensen HB, Skogstrand K, Pociot F, Johannesen J, et al. Levels of soluble TREM-1 in children with newly diagnosed type 1 diabetes and their siblings without type 1 diabetes: a Danish case-control study. Pediatr Diabetes. 2017; 18(8):749-54.

172 Grigsby JG, Cardona SM, Pouw CE, Muniz A, Mendiola AS, Tsin AT, et al. The role of microglia in diabetic retinopathy. J Ophthalmol. 2014;2014:705783.

173 Francis PT, Palmer AM, Snape M, Wilcock GK. The cholinergic hypothesis of Alzheimer's disease: a review of progress. J Neurol Neurosurg Psychiatry. 1999;66(2):137-47.

174 Domínguez-Cáceres MA, García-Martínez JM, Calcabrini A, González L, Porque PG, León J, et al. Prolactin induces c-Myc expression and cell survival through activation of $\mathrm{Src} /$ Akt pathway in lymphoid cells. Oncogene. 2004;23(44):7378-90.

175 Zhu M, Liu M, Guo Q-L, Zhu C-Q, Guo J-C. Prolonged DADLE exposure epigenetically promotes $\mathrm{Bcl}-2$ expression and elicits neuroprotection in primary rat cortical neurons via the $\mathrm{PI} 3 \mathrm{~K} / \mathrm{Akt} / \mathrm{NF}-\kappa \mathrm{B}$ pathway. Acta Pharmacol Sin. 2018;39(10):1582-9.

176 Popiolek-Barczyk K, Mika J. Targeting the microglial signaling pathways: new insights in the modulation of neuropathic pain. Curr Med Chem. 2016;23(26):2908-28.

177 Rivero-Segura NA, Coronado-Mares MI, Rincón-Heredia R, Pérez-Torres I, Montiel T, Pavón N, et al. Prolactin prevents mitochondrial dysfunction induced by glutamate excitotoxicity in hippocampal neurons. Neurosci Lett. 2019;701:58-64.

178 Rivero-Segura NA, Flores-Soto E, García de la Cadena S, Coronado-Mares I, GomezVerjan JC, Ferreira DG, et al. Prolactin-induced neuroprotection against glutamate excitotoxicity is mediated by the reduction of [Ca2+]i overload and NF- $\mathrm{KB}$ activation. PLoS One. 2017;12(5):e0176910.

179 Kim SK, Woodcroft KJ, Khodadadeh SS, Novak RF. Insulin signaling regulates gamma-glutamylcysteine ligase catalytic subunit expression in primary cultured rat hepatocytes. J Pharmacol Exp Ther. 2004;311(1): 99-108.

180 Duc Nguyen H, Hoang NMH, Jo WH, Ju RH, Mi-Kyung L, Kim MS. Associations among the TREM-1 pathway, tau hyperphosphorylation, prolactin expression, and metformin in diabetes mice. Neuroimmunomodulation. 2021. Epub ahead of print.
Interaction between Prolactin and

Diabetes in Neurodegeneration
Neuroendocrinology 2022;112:856-873

DOI: $10.1159 / 000521653$ 